Öz

Normlar ve idari yapılara bağlı oluşmuş, geliştirilmekte ve dönüştürülmekte olan biçimlerin, özellikle de yapılı çevrenin insan doğası, hakları ve güvenliğine uygunluğunun sorgulanmasında, özgürlük idealinin gündemde tutulmasının önemli rolü bulunur. Kavramsal olarak, özgürlük anlayışı ve baskıya mutlak karşıtlığı kapsayan düşünce akışı, anarşist felsefe ile ele alınmıştır. Anarşist yazında özgürlükçü tutumların öne çıktığı kimi dönemler ve mekanlar, simgeleşmelerine rağmen anarşik olarak nitelendirilmemiştir. Anarşist olarak nitelendirilen tutumları mekânsal tanımlamalarla buluşturan özgürlük kavramı, insan-çevremekan ilişkilerinde, çoğunlukla, baskı ve gerilim oluşturan olgular ile gündeme gelmektedir. Süregelen mekânsal tutumlarda özgürlüğün öne çıktığı eğilim ve hareketler ise, mekanı üreten ve kullananların yaşam ve özgürlük kavrayışları ölçüsünde, bulundukları mekan ve zamanın kalıplarını olduğu kadar kısıtlayıcı ve statükocu kalıpları aşma biçiminde açığa çıkabilmektedir. Bu bağlamda farklı dönem ve kültürlere özgü mekânsal gelişmelerdeki tutumları çakıştırmak, özgürlük gereksinimi ile gelişen tutumların insan-çevre-mekan ilişkilerinde nasıl etkiler bıraktığını açığa çıkarır ya da görünür kılar.

\section{Abstract}

Keeping freedom as an ideal on agenda is essential for the interrogation of norms and forms that have been constituted, generated and cultivated with relevance to the convenience of man-made environment to

human nature, rights and security. Regarding this ideal, the current of thought, conceptualy comprising freedom as absolute rejection of repression and dominion has been developed within the anarchist philosophy. The attitudes that are characterised as anarchist and spatial definitions coincide through freedom as a term, then come into question along with repressive facts concerning human-environment-place relations. In spatial develeopments, prevalent tendencies and movements are emerged and spreaded with extent of determinations of those that produce and use the places in this context; and are revealed over manners that exceed the status quo patterns repressing time and place. In this context, cross-cultural evaluations on human-environment-place relations released from place-time limitations would potentially reveal and highlight brandnew relations concerning diverse attitudes on spatial developments through need for freedom.

Anahtar Kelimeler:

Mekan, Özgürlük, Temsil, İfade, Norm. Keywords:

Place, Freedom, Representation, Expression, Norm.

\title{
özgürlük ve Baskının Mekansal Temsili
}

Doktora Makalesi

\author{
Eser Yağçl, Nesrin Dengiz \\ Mimar Sinan Güzel Sanatlar Üniversitesi \\ Mimarlık Fakültesi, Mimarlı Bölümü
}

MSGSÜ, Fen Bilimleri Enstitüsü, Mimarlık Programı'nda tamamlanmış "İnsan-Çevre-Mekan İlişkilerinin Ífade ve Etkileşim Aracı Olarak Kullanımları: Özgürlü̈̆̈̈̈n Mekansal Temsilleri” başlkkl tezden 9 Nisan 2014 tarihinde oluşurulan bir makaledir. Makale metni 15 Nisan 2014 tarihiyle dergiye ulaş̧ııs, 30 Nisan 2014 tarihinde basım kararı alınmıştır. Makale ile ilgili tartışmalar 30 Kasım 2014 tarihine kadar dergiye gönderilmelidir.

İnsan üretimi olan her mekan varlık gösterdiği sürecin çevresel ve yaşamsal izlerini taşımaktadır. Mekanın insandan insana, topluluktan topluluğa değişen anlamı, çevreden edinilen izlenimler ve etkiler kadar, insanın sürekliliği ve sonrasında kimliğini tanımlama ve göstermesine bağlı olarak gelişmiştir. Mekan, ihtiyaçların çeşitlenmesi ve toplu yaşama geçilmesi ile bir takım amaçlara yönelik kurgulanırken fiziksel örüntüler kadar farklı tinsel gereksinimleri de yansıtmaya başlamıştır. Bu aşamalarla, bir takım normlara tabi olarak, teknik ve bilgi standartlaşması ile özerk bir bilgi alanı olarak mimarlık oluşmuştur.

Mekan, mimarlığın kullandı ̆̆ bilgi kapsamı ve ürünü haline gelmeden önce de, insana, zamana, doğaya ve yaşama uyumu ölçüsünde varlığını sürdürmüştür. Başka bir deyiş ile, her dönemde mekan, varlığının tanımlandığı uzamın, fiziksel ve sosyal koşullarına uyumluğu ölçüsünde sürekli olmuştur. Süreçler içinde, mekan oluşturmanın bir takım paradigmalara bağlanması, mekanın toplumsal yaşamı örgütleyen kurallara bağlanmasını beraberinde getirmiştir. Böylece oluşan ve artan paradigmaların erk odaklarınca belirlenmesi, aynı oranda mekanın özgürlük ile bağının zayıflaması anlamını taşımaktadır.

Bu kabuller ile, mekanın mimarlık disiplininin paradigmalara bağlı yapısına tabi olarak tanımlanması, üretilmesi, geliştirilmesi ve çözümlenmesi, mekanda özgürlüğü, mimarlık alanındaki paradigmaların belirleyicilerinin eline bıraktığı kadar, bu belirleyici aktörleri yönlendirebilen diğer erk unsurlarının da mekan üzerindeki kontrolünü sağlamaktadır. Mimarlık tarihinin konusu olan mekânsal gelişmeler, uygarlık tarihindeki gelişmeler, dönüm noktaları, başlangıçlar ve yok oluşlar ile ilişkilidir. Mekanın insanı biçimleme gücü oranında bu değişimler, mekan üzerinden yine insana yansıyarak toplulukları ve eğilimlerini biçimleyebilmektedir. Bu nedenle tarih boyunca mekan, erk odaklarının insan davranışlarını yönlendirmekteki en eski ve etkili 
araçlarından biri olmuştur.

Antik Çağ'dan bu yana, bir çok düşünürün insan ve politika arasında kurduğu ilişkiler, mekanın rolünü de kapsamış, mekan hiyerarşisi üzerinden insan davranışları üzerinde denetim kurulması olgusu farklı alanlarda ele alınmıştır. Bu bağlamda en fazla kullanılan örnek, günümüzdeki toplumsal denetim yapılarıyla ilişki kurması ile toplum bilim çalışmalarında geçerliliğini sürdüren, Foucault'nun "Hapishanenin Doğuşu" başlıklı çalışmasıdır (2000). Bu çalışma, Jeremy Bentham'ın mimari önerisi olan Panopticon Hapishanesi'ndeki mekânsal kurguda belirginleşen ve bir dizi hapishane şemasında da açığa çıkan, mekânsal hiyerarşinin insanı baskılamak ve kontrol etmekteki belirgin etkisini ele almasıyla öne çıkar. Foucault'nun (2000) teorisinde, modern iktidar yapıları ve diğer erk mekanizmaları kontrolünde, bireysellik yanılsaması ile bu mekanizmaların tasarımı olan ve gözetim altındaki mekanlardan oluşan bir sahne içine hapsedilmesi olgusu, süregelen bu kurgunun modern toplumlarda daha da güçlü bir biçimde kullanımda olduğu yargısını güçlendirmektedir. Bu teorik ilişki, kendisinden sonraki kuramsal çalışmalara altlık oluşturmaktadır.

Panopticon'daki merkezi konumda olan gözlem kulesi gibi, Stolleis'in ele aldı $\breve{g} 1$ merkezi iktidarın simgesi olarak “Tanrı'nın Gözü İmgesi” belirli biçimleri güç göstergeleri olarak ele almaktadır (2009, 48). Bu imge ve biçimler, iktidarın gözü ya da hükümdarın gözü olarak Eski Çă̆ Mezopotamyası'nda, Antik Mısır'da Ra'nın sembolü ve tanr1-kral Osiris'in asasındaki göz (Stolleis 2009, 25), -aynı zamanda “Tanrının Gözü İmgesi” nin üçgen formu ile bir arada kullanıldı $\breve{g}^{-}$
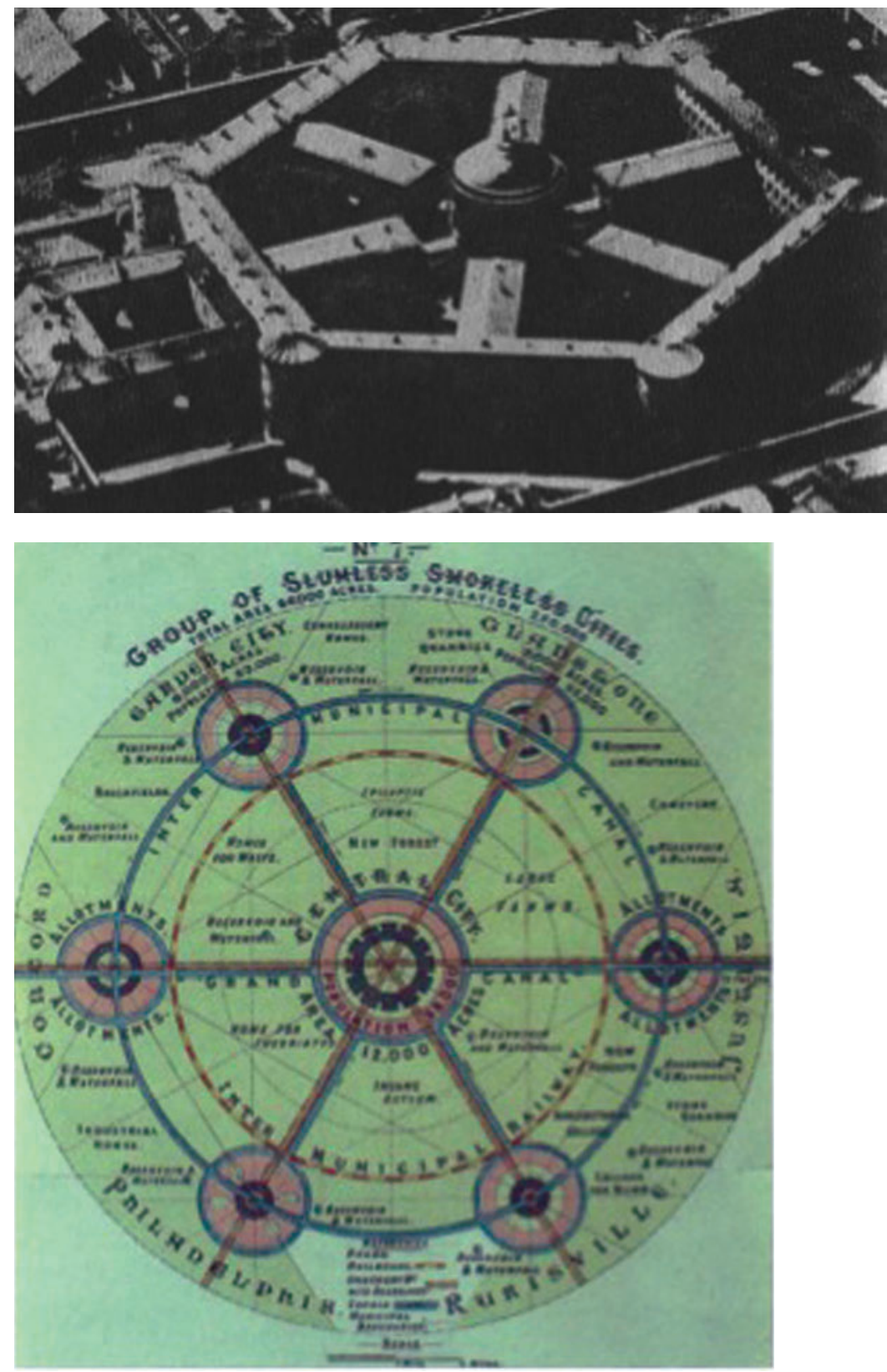

Orta Çağ boyunca bazı gizli öğretilerin de simgesi olarak kullanılmıştır. Bu simgenin Fransız Devrimi sonrasında özellikle modern hukukun yapılanmasına tanıklık eden 19. yüzyıldan itibaren, yurttaşın Resim: I

Petite Roquette Hapishanesi (Foucault 2000).

Resim: 2 Ebenezer Howard - Bahçe Kent şeması (1902). ulusu tarafından gözetilmesi anlamında bir metafor olarak kullanılmak kaydıyla, “yasanın gözü”ne aktarılıp modern yasaların simgesi olarak sıklıkla kullanılması, Stolleis (2009, 35-36) 
tarafından özgürlüğün, adaletin ve eşitliğin, iktidarın belirlediği normların çizdiği sınırda sağlanması olarak yorumlanır. Benzer bir kurgu ile, biçimler ve simgeler, mekan ve denetim ilişkisini gösteren birer metafor olarak değerlendirildiğinde, Babil'den bu yana birçok Orta Çağ ütopyasında ve kentinde olduğu gibi, 19. yüzyılda endüstrileşen kentlerde işçi konutlarından, 20. yüzyılın başında üretilen bazı kent planlarına kadar, iktidarın gözünün tüm mekanların en tepe noktasinda ve merkezinde konumlandığı 1şınsal şemalar (Resim 1 ve 2) olduğu fark edilir. Bu merkezi yapı, sosyal açıdan eşitlikçi görüşü vurgulayan 20. yüzyıl şehircilik yaklaşımlarında da etkisini sürdürse de (Foucault 2000), mekan hiyerarşisi nihayetinde disiplin ve kontrol düzeneği olarak okunmaktadır.

Mekanın kontrol ve denetimin odağ haline gelmesi, kolektif hafızada yer edinmesi ile başlayıp sosyal ve politik pratiklere yön verme aracı haline gelmesi ile olmaktadır. Massey’e (1994, 254) göre 1970'lerin teorik ortamında "mekanın toplumsal bir yapı olması" görüşü hakimken, 1980'lerde "toplumun mekânsal olarak yapılanması" düşüncesi ağırlık bulmaktadır. Her iki durumda da "mekan, potansiyel olarak tarih ve politikanın üretimi ile ilişkilenmektedir". Bu bakışla sözü edilen ilişki yoğunlaştığı oranda, mekan ile özgürlük arasındaki ilişki zayıflamaktadır. Varlık sürdürdüğü dönemin politik görüşüne aykırı olan tüm biçimler ve biçemlerin, kısıtlama, baskı ya da yok edilmeye maruz kalması olgusu da bunda etkilidir.

Mekanın politik bir içerik barındırması, bu içeriğin bağlı olduğu tutarlılık ve düzen tanımına bağlı olarak mekanın işlevi, biçimi, biçemi ve detaylarını simgeleştirmektedir. Leach'in (1999, 5) yorumuna göre, "eğer politik içerik dolaylı ya da belirsiz ise mekanın sosyal bağlamı da hafızadan silinmektedir". Bu yoruma göre, yapının çağrıştırdığı tüm değerler kaybedilmektedir. Mekanın, insanı kurgusal bir düzene alıştırma ve koşullama gücü doğrultusunda, çoğunlukla sosyal, ekonomik ve politik kullanımlarında kimi zaman özgürlük de bir yanılsama olarak sunulmaktadır. İdeal kentler, mikro uluslar, alternatif yaşam alanları, yaşam tarzı komünleri gibi çeşitlenen mekânsal oluşumların bir bölümü, bu bağlamda sunumlara uymakla birlikte, bir kısmı yaşam akışındaki karmaşanın ifade alanı olarak oluşup anarşiye yaklaşırlar.

Özgürlük, insanlık tarihi boyunca üretilmiş somut ve soyut her mekan üzerinde tartışılabilir bir kavramdır. Ancak özgürlüğün kullanımında hangi mekanın anarşist bir tutumu temsil etmeye yaklaştığı görecelidir, bu bağlamda temsiller süreçler içinde değişmektedir. Tarih okumalarında, özellikle varlığını sürdürdükleri zaman ve mekanın baskı unsurlarını -mülkiyeti, kurumları, toplumsal, teolojik ve siyasi yapılara bağlılığa karşı olan- bir takım birey ve toplulukların ilişkili oldukları mekanlarla anıldı ̆̆1 ya da etkinlik gösterdikleri mekanın bu kişilerin aykırı tutumlarının simgesi haline geldiği örnekler bulunabilir.

$\mathrm{Bu}$ konudaki ayrımı belirginleştiren önemli örneklerden biri, kendine has gizemli öğretilerine bağlı oldukları düşünülen Katharlar'ın mekansal izleri olarak, Fransa'da Toulouse ve Montpellier kentleri arasında kalan bölgedeki özellikle Carcassonne'da- Kathar kaleleri ve şatolardır. Günümüzde Fransa'nın 
emlak ve turizm sektörünün uluslararası pazara açtığ 1 ve Kathar efsaneleri üzerinden pazarlanan bu yapilar (URL-4, 2012) 1208'de Papa III. Innocentius'un bildirgesi ile başlayan Kathar Haçlı Seferi'nde talan edilmiş ve 20.000 kadar katharın soykırımına tanıklık etmiştir ${ }^{\prime} .11$. ve 13. yüzy1llarda Roma Katolik Kilisesi'ni en fazla tehdit eden unsur olarak Haçlı Seferi'ne götürecek kadar aykırı bulunan bu yaşam biçimine ait yapılar çeşitli efsanelerin yeniden üretilmesi üzerinden tüketime sunulmaktadır.

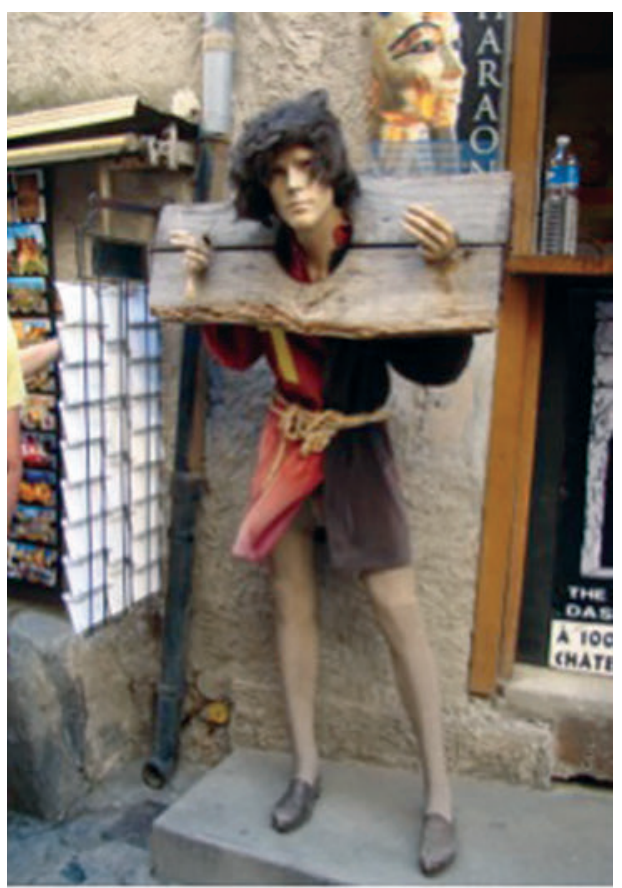

UNESCO tarafından 1997 yılında Dünya

Kültür Mirası Listesi'ne alınan kale içi gibi, Kathar efsaneleri ile turların düzenlendiği Languedoc bölgesi Fransa'nın en turistik bölgelerinden birine dönüşmüştür. Orta Çă̆ Avrupası için anarşist olan Kathar Haçlı Seferi, restore edilerek yeniden üretilen mekanların, bir zamanlar yok edilmek istenen bir anlayışın yapıları, kalıntıları ve anıtları olarak (Resim 3), reklam, göstergenin kopyalanması, makyajlanması, canlandırması yoluyla anlamlı kıldığı içerikler boşaltılmaktadır. Bu yapılar, anarşizmin mitler ve efsaneler ile yeniden üretilerek modalaşması ve metalaştırılması gibi ikili bir işlev taşımaktadır.

Baudrillard'ın "Simgesel Değiş Tokuş ve Ölüm” çalışmasında (1998, 100-137) çeşitli örneklerle ele aldığg gibi, reklam ya da efsanenin yeniden üretimi yoluyla, bu yapıların birer gönderen olarak bir zamanlar temsil ettiği aykırı kimlik, moda sistemi tarafından tersyüz edilip alegorik olarak birer makyaj malzemesine indirgenmektedir. Bu örnek aynı zamanda, anarşizme yaklaşan tutumların estetik kültürdeki popülerliğine denk gelir ve anarşinin mekanla ilişkisinin çelişkisini gösterir.

Avrupa'daki örneklerinden daha önce, coğrafi olarak Anadolu, Balkanlar, İran, Suriye, Mısır ve Hindistan'da daha çok iz bıraktığı düşünülen aykırı yaşam biçimlerinin birbirleri ile etkileşimlerinden izler taşıyan, toplumsal yaşamın göstergesi olan toplumsal ve mekânsal normları reddeden kişiliklerin çeşitli mekanlarla birlikte anıldığg örnekler bulunur. Örneğin Erzurum yakınlarında bir "deliler kenti" varlığından bahseden Karamustafa (2007, 12), özellikle 14. ile 16. yüzyıllar arasında Osmanlı topraklarında da "Kalenderler", "Abdâllar", "Haydarîler" gibi çeşitli derviş gruplarının aykırı yaşam biçimlerini ele alır. Haydarîler'in kendilerine ait küçük tekkeleri olan bekarlar olarak dini kurallara karşı geldikleri bilinmektedir. Ancak bu gruplardan hangilerinin mekanlaşmayı reddettikleri hangi kurallara hangi dozda karşı geldikleri kesinleştirilememektedir. Anadolu'da dolaşan bu dervişlerin, sabit bir mekanda durmayıp, kimilerinin şehir merkezindeki üst sınıfları açıkça rahatsız edecek
Resim: 3

Günümüzde Carcassonne Kaleiçi turistik hediyelik eşyalar satan dükkanlar oteller ve restoranlarla dolmuştur (Eser Yağfı, 2011).

I Kökleri Kuzey Mezopotamya'daki Manes ögretisine dayandığı düşünülen (Kirikkanat 2008) Kathar inancının, oldukça benzer ikilcil/düalist yaklaşımı içeren Anadolu üzerinden Bogomizm olarak eurilerek Bulgaristan'a gesip Orta Aurupa'ya yayılması hipotezi bulunur.

2 Château comtal de Carcassonne (Fr.) 


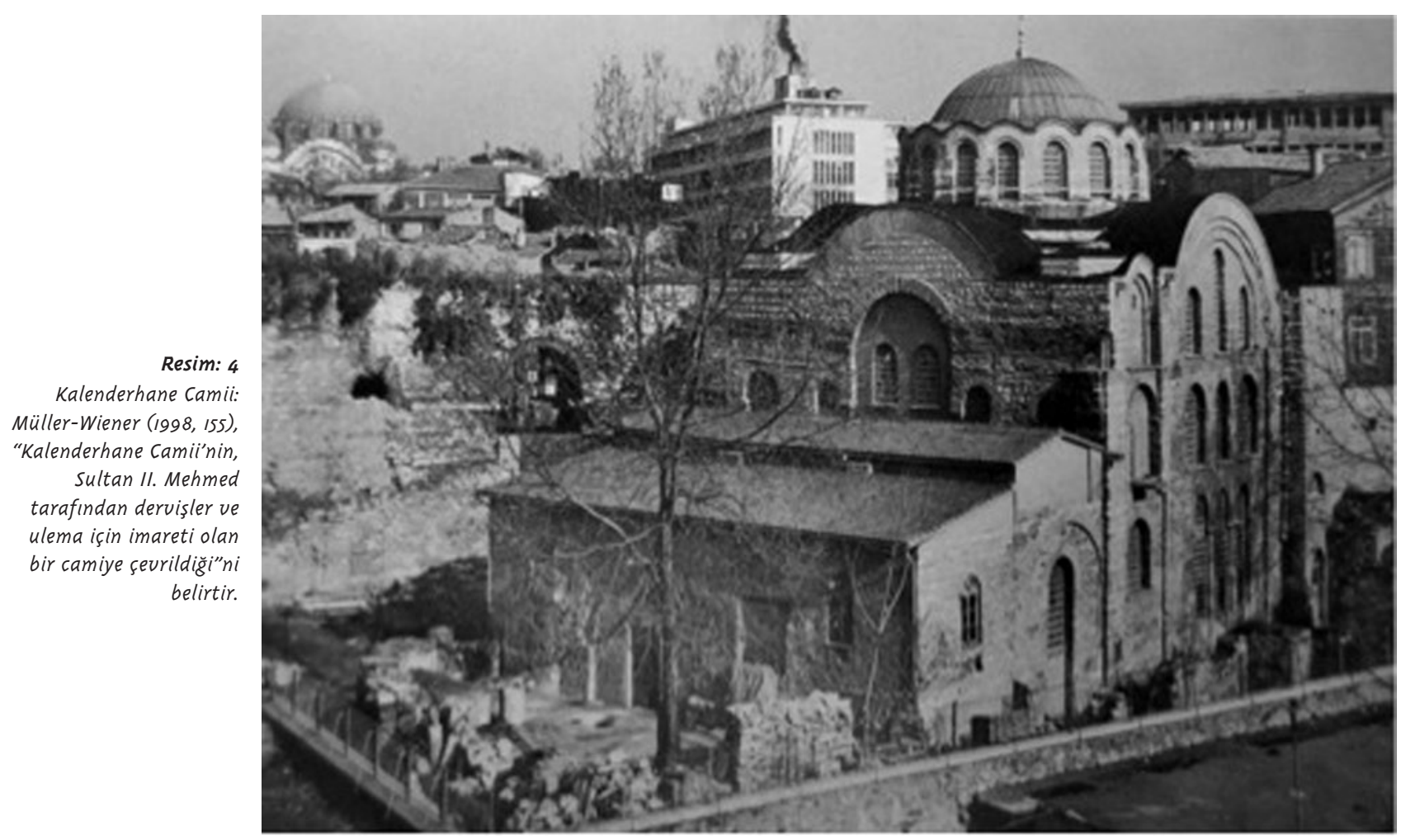

davranışlar sergiledikleri, kimilerinin toplumsal yaşama aykırı düşen çıplaklık, aşırı bireysellik, esrar kullanımı, gürültü çıkartma, tüyleri tamamen tıraş etme gibi biçimlerle sapkın ya da anarşist tutumlar sergiledikleri edebi kaynaklardan anlaşılmaktadır. II. Mehmet döneminde kurulan zaviyelerinin olduğu ve bunların kentlilerden gelen şikayetler üzerine ferman yoluyla araştırma altına alındığı ancak bazı dervişlerin, dilekçe ile kentlileri zaviyenin arsasına göz koymakla suçlaması örneği (Karamustafa 2007, 86) egemen sınıf ile aykırı gruplar arasındaki kentsel gerilimin İstanbul'un Türklerin eline geçmesinin ilk yıllarına kadar takip edilebileceğini göstermektedir.

Karamustafa'nın Fatih Mehmed II Vakfiyeleri'ne dayanarak belirttiği, Müller-Wiener'in de "İstanbul'un Tarihsel Topografyası"nda (1998, 153-159) yer verdiği gibi, daha önceden Bizans hamamı ve kilisesi olarak kullanılan Kalenderhane Camii (Resim 4), Fatih Sultan Mehmet'in kişisel isteği ile Kalender derviş grubuna verilmiş bir yapı olarak açığa çıkar. Karamustafa'nın yorumu ile "kendilerini toplumsal düzene planlı bir direniş yoluyla tanımlayan" bu dervişlerin Sultan II. Mehmet'in hükümdarlığı süresince tekkeler ve zaviyelerde mekanlaşmaları sonrasında da süreklilik gösteremedikleri ya da anarşist tutumlarının yok olduğu anlaşılır. Bu örnek üzerinden aykırı tutumu sürdüren birey ve grupların mekanlaşma yoluyla homojenize olduğu söylenebilir.

Osmanlı İmparatorluğu'nda nüfus yapısı içinde aykırı bulunan kesimlere karşı, önlem ve uygulamalar artarak devam etmiştir. Özellikle, III. Selim dönemi, bazı tarihçiler tarafından (Başaran 2007, 116-134), "Batı tarzı" reformlarla adalet işleyişinde önemli düzenlemeler ile anılmaktadır. Bunun dışında, Osmanlı kent yaşantısını ve kentlerin gelişimini etkileyecek katı uygulama ve yaptırımların başladığı bir 
dönem olarak da değerlendirilir. Bu dönemde, İstanbul ve diğer büyük kentlere göçte kısıtlamalar olduğu kadar, tutulan Kefalet Defterleri, devlete göre meşru bir işi olmayan azınlık ya da başıboş kişilerin denetim amacıyla, daha detaylı kayıt altına alındığ 1 belgeler haline getirilmiştir. $\mathrm{Bu}$ defterler içinde, bir takım medrese, tekke, zaviye, diğer dini yapılar ve belirli mahallelerle ilgili belirli kayıtların da olduğu belirtilmektedir. Başaran'ın çalışmasında (2007) yer aldığı gibi, bu kayıtlara göre toplum içinde tehdit oluşturanlar olarak sınıflandırılan, başıboş gezen "serseri, bekar ve işsizler"in "gizli saklı hanlar ve bodrumlar" gibi karanlık ya da terkedilmiş mekanlarda ikame ettiklerinden söz edilmiştir. İstanbul'da sur içi, Eyüp, Üsküdar, Galata ve Boğaziçi sahillerine ait defterler, özellikle bu dönemde mahallelerdeki yapı işlevleri, meslek alanları ve yaşayanlar ile ilgili kayıtların detaylanması, merkezi iktidarın denetimini mekan üzerinde de arttırdığını göstermektedir.

\section{Özgürlüğün mekânsal kurgularda} simgeleştirilmek kaydı ile kullanımları, iktidar odaklarının belirsizleştiği günümüz düzeninde daha da yaygınlık bulur. Bu nitelendirmeye göre, mekanın teknik, işlevsel, estetik biçimlenmesi kadar sosyal bağlamını da kurgulama ve yönlendirme erkini kullananlar, oluşturduğu ağ ilişkileri ile, özgürlüğü faydacı bir kurguda kontrolle kullanıma sokmaktadır. Kathar efsanelerinin kullanımları gibi, özgürlükçü ütopyaların yeniden üretilmiş biçimleri olarak ideal kentler de yeni ekonomik ve siyasi düzeneklere örnek oluşturmaktadır. Miles'ın (2008), "alternatif yerleşimler"3 olarak incelediği ve ütopyalardan esin aldıklarını düşündüğü örneklerin büyük bölümü, pratikte, özgürlükleri belirlenmiş ayrıcalıklı bir kitlenin kullanımına sunulan uzamlardır. Auroville, gerek bu sunuma uymas1, gerekse işgücü sömürü düzenini ulus ötesi ve eşitlikçí gibi söylemler ile maskeleyip post-kolonyal eleştirinin hedef alabileceği bir örnektir.

Hindistan'ın güneyinde öncelikle bir aşram olarak kurulan Auroville yerleşkesi, 28 Şubat 1968 'den günümüze kadar resmi olarak tüm dünyadan misafirlere açılmış, uluslararası bir ideal kent olarak gelişmesini sürdürmektedir. Auroville, başlangıçta Cambridge'de eğitimini görmüş ve Gandi'nin düşünce ve kurduğu aşramdan ve bu mekanın ev sahipliği yaptığı özgürlük mücadelesinden etkilenen Sri Aurobindo ile günümüzdeki kentte "Anne"s olarak anılan doğduğu Paris'te aldığı sanat eğitimi sonrasında Japonya ve Hindistan'a giden Mirra Alfassa tarafından kurulur (Miles 2008, 184-195). 1965 yılında Fransız mimar Roger Anger tarafından tasarlanan kent, 1968'de Hindistan hükümeti yanı sıra UNESCO'nun desteğini alır. Anger (URL 3, 2012), bu ekolojik kentin tasarımını üstlenirken Le Corbusier'den etkilendiğini belirtse de, dört sektörden oluşan işınsal düzende (Resim 5), farklı beğeni, araștırma ve yatırım

\footnotetext{
3 Alternative settlements (Ing.)

4 Egalitarian (Ing.)

5 "The Mother" (Ing.)
}

Resim: 5

Auroville Yönetim Alanı HaritasI (URL-4, 2012): I. Gelecekteki Belediye Binası Alanı,

2. Auroville Kent Araştırmaları Merkezi, 3. Kafeterya (yapım aşamasinda), 4. Multi-medya Merkezi (yapım aşamasında), 5. Park, 6. CIRHU Oteli (yapım aşamasinda), 7. Matrimandir Gölü (gölün f̧apı henüz kesinleşmemiştir), 8. Matrimandir Alanı.

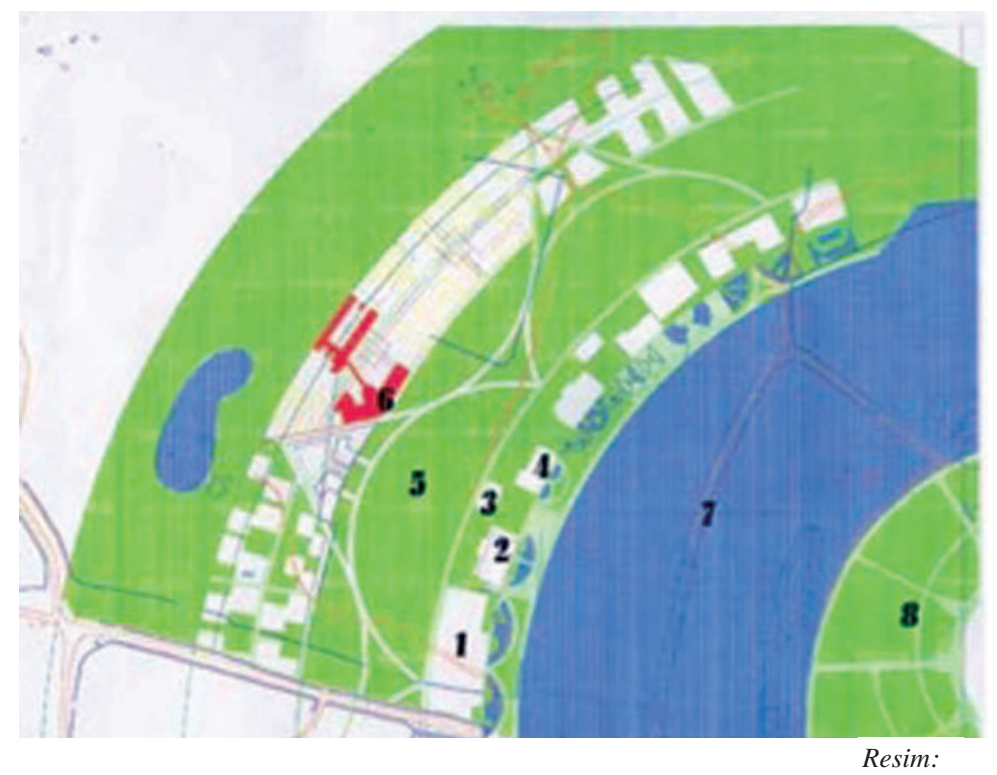




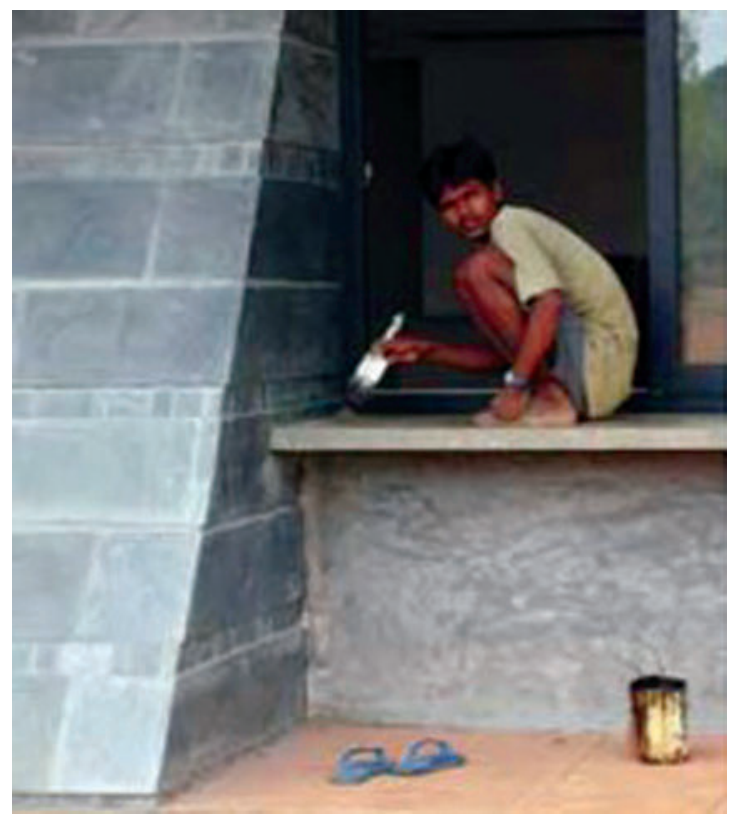

Resim: 6 odaklarının isteklerine uyacak çeşitli

Auroville Kentsel Araştırmalar Merkezi Inşaatı (URL-6, 2012).

Tablo: I Auroville'de inşaat işlerinde Çalısanların Uyrukları ve Oranları (URL-6, 2012). yapılar tasarlanır. Auroville'in mimarisi üzerine Auroville internet sitesinde yer alan ve 2002 Ekim ayında sanal gazetede paylaşılan köşe yazısına göre, bu çeşitlilikteki yapıların artık birbiriyle çelişir hale geldiğinden ve değişen misafir profilinin yarattığı soylulaşma yanı sıra, bir o kadar Auroville kuralları dışında resmi olmayan barınmalardan ve işgalden yakınılmaktadır.

Günümüzde, uluslararası birçok kurum ve organizasyon tarafından fonlar ve projeler ile desteklenen, aynı zamanda her gün binlerce turiste sunduğu alternatif, spiritüel, organik, ekolojik gibi kavramlar başlığında servis veren bu yerleşim alanının kendi ekonomisi de sanal ortamda güncellenerek yayınlanmaktadır. $\mathrm{Bu}$ yayınlardan (URL-5, 2012), Auroville misafirlerinin üçte birinden daha düşük bir oranın yerel halktan olduğu buna karşın yayınlanmış (Resim 6 ve Tablo 1) araştırma tarihinde tespit edilmiş olan 4179 çalışanın 3709'unun büyük çoğunluğunun Hindistan vatandaşı, küçük bir kısmının Nepal vatandaşı olduğu anlaşılmaktadır.

\begin{tabular}{lll} 
ÇALIŞANLARIN UYRUKLARI & Sayı & Yüzde \\
Hindistan & 3650 & 98.41 \\
Hindistan Vatandaşı Olmayan & 8 & 0.22 \\
Nepal & 51 & 1.38 \\
\hline Toplam & 3709 & 100 \\
ÇALIŞANLARIN GELDİĞİ BÖLGE & Sayı & Yüzde \\
PONDICHERRY & 891 & 24.02 \\
TAMIL NADU & 2730 & 73.6 \\
FARKLI & 88 & 2.37 \\
\hline Toplam & 3709 & 100 \\
& & \\
ÇALIŞANLARIN DOĞUM YERİ & Sayı & Yüzde \\
TAMIL NADU & 2630 & 70.91 \\
PONDICHERRY & 980 & 26.42 \\
NEPAL & 59 & 1.59 \\
DİĞER & 40 & 1.08 \\
\hline Toplam & 3709 & 100 \\
\hline
\end{tabular}

Şiddet içermeyen sivil direniş̧in öncüsü olarak anılan Mahatma Gandi'nin oluşturduğu ve 1917 ile 1930 yılları arasında Hindistan'ın bağımsızlık mücadelesinin önemli direniş merkezlerden biri olarak hatırlanan Sabarmati/Harijan Aşramı ile, aşramlar özgürlük mekanları olarak simgeleşmiştir. (Galtung 2001, 209-223) Sabarmati Aşram1, Hindu öğretisine bağlı binlerce yıldır varlığını sürdüren mekanlar içinde Gandi'nin "şiddete dayanmayan direniş biçimi"ni kavramsallaştırdığ 1 ve "gerçeğe ulaşma çabası" anlamına gelen Satyagraha öğretisinin yayıldığg 1 bir mekan olarak öne çıkmaktadır. Thoreau'nun "sivil itaatsizlik" olarak kavramlaştırdığı (Coşar 2001), pasif direnişin dünya tarihindeki öncü örgütleyicilerinden biri olan Gandi, özgürlüğün şiddet içermeyen yöntemlerini uygulamaya koymuştur. Sabarmati, Hindistan'da kitlesel eylemlerin merkezi olarak 1930 yılında hükümet tarafından ele geçirilmiştir. Sabarmati, özgürlüğün mekanda simgeleşip, bu simgelerin imaj olarak kullanıldığı Auroville gibi tasarımlara ilham vermektedir (URL-7, 2012). 
Hindistan dışında günümüzde de etkili olan benzer alternatif yaşam biçimleri ve bunları yansıtan özerk yerleşim alanları tasarlanmaktadır. Bunların bir kısmı anarşist felsefe etkisinde gelişen ideal yaşam ve yerleşim alanları ya da eşitlikçi kentler olarak da adlandırılmaktadır. Sözü geçen örnekler, farklı bir takım parametreler doğrultusunda yürürlükte olan ekonomik ya da politik düzenin dışında bir yaklaşım ortaya koysalar da, medyalaştıkları ölçüde karşısında oldukları ideolojik yapılara kolayca eklemlenebilmektedirler; ya da en başından itibaren maddi ve idari bağları ile yeni sömürge düzenekleri olarak biçimlendirilmektedirler.

Anarşist düşünce ve yansımasını bulduğu mekânsal pratiklerin değerlendirilmesinde, bu örnekler gibi post-kolonyal eleştirel teorinin açtığı perspektif (Dirlik 2010), paralaks teorinin (Karatani 2008) önermiş olduğu gibi farklı okumalar ve ilişkiler kurulması yolunda yöntem önermektedir. $\mathrm{Bu}$ gibi yöntemler, hakim bakış açısını değiştirmek ve daha önceden fark edilmemiş ilişkileri açığa çıkartmak amacında felsefi kurgular gelişmesinde etkili olmaktadır. Özellikle post-kolonyal eleştirel teori, Batı Felsefesinde ele alınan anarşiyi yine kendi üretimi olan oryantalizm üzerinden okumakta, ulus ötesi ağların özgürlük kurguları ile örülen ve estetize edilen anarşiyi mekanda ya da eylemde çelişki olarak tanımaktadır. Bu bakış açılarıyla, günümüzde, ulus ötesi ağların insan ve mekan üzerinde artan baskısı, yaşam alanlarını daraltması olgusu belirginlik kazanır. Aynı kavramsal bakışa göre, post-kolonyal yaklaşımda üçüncü dünya ülkeleri olarak tanımlanan yerlerin ötesine geçmiş ve gelişmiş olarak nitelendirilen ülkelerde de görülür hale gelmiştir. Davis'in Gecekondu Gezegeni başlıklı çalıșmasında (2007), ağırlıklı olarak Batı'ya servis veren endüstri kollarının kentsel nüfusu hızla şişirdiği Çin, Hindistan, Güney Amerika, Orta Doğu'daki kentlerde, kentsel mekandaki hızlı dönüşümün küresel ekonomipolitikalarla ilişkilerini değerlendirilir. Ancak dünyanın çok farklı noktalarında farklı ölçek ve görünürlükte de olsa barınma hakkı ihlallerinin, sosyal ayrışma, medya spekülasyonu, sektörler arası rekabet, ekonomik büyüme yarışı gibi olgularla empoze edildiği, meşrulaştırmalar yanı sıra yasal düzenlemelerde açıklar ile desteklendiği ve yaşam hakkını kısıtlayacak kadar ileri gittiği vurgusunda bulunan eleştirilerin sayısı artmaktadır. Bu olguların, küresel kent söylemi içinde birbiri ile rekabete giren tüm kentlerde kendini göstererek üçüncü dünyadan gelişmiş olarak kabul edilen ülkelere sıçramış olduğu yönünde saptamalar bulunur (Wilson 1991, 121-134). Kentlerin artan bir şekilde birbirine benzemeye başlaması, çoğul kullanıma açık ve bulunduğu yerin bağlamından kopuk mekanların tek-tipleşmesi üzerinden görülmektedir. Günümüzde mega kent olarak anılan büyük metropoliten alanlarda özgürlük, yalnızca, ulus ötesi ağ içinde etkin konumda olan kurum ve şirketler ile ekonomik ve siyasi güce sahip olanlara, belirli siyasi ve ekonomik sınırlarda tanınır hale gelmiştir.

Birleşmiş Milletler'e bağlı (UN-HABITATAGFE 2011, 10), İnsan Yerleşimleri Programı Zorla Tahliyeler Danışma Grubu' ${ }^{6}$ nun 2011 yılı raporlarında, Arjantin, Botsvana, Brezilya, Çin, Kolombiya, Dominik Cumhuriyeti, Misır, Fransa, Gana, Guatemala, Honduras, Hindistan, Endonezya, İsrail, İtalya, Kenya, Meksika, Nijerya, Pakistan, Peru, Filipinler, Senegal, Güney Afrika, Sri Lanka,
${ }^{6}$ Advisory Group on Forced Evictions (Ing.) 
Uganda, Birleşik Krallık, Amerika

Birleşik Devletleri ve Zimbabve'de güncel ve planlı olan zorla tahliyelerin tespiti ve takibinin yapıldı $\breve{g}$ belirtilmektedir.

Barınma Hakları ve Tahliyeler Merkezi COHRE (2009, 8) 2007-2008 istatistiklerine göre, dünyada 4.5 milyon kişi tehdit ve uygulamalar ile tahliyeden etkilenmiş, bunlar içinde 1.5 milyon insan zorla tahliyeye maruz kalmıştır. Zorla tahliyelerin, iklim değişikliği, doğal kaynaklardan fayda sağlamaktan, etnik ayrımcılığa bağlı nüfus takasına kadar çeşitlenen nedenlerine gün geçtikçe yenileri eklenmektedir. Aynı bağlamda, nüfus akışının adı geçen ülkelerdeki hızla büyüyen kentlerin de oluşturduğu "düzensiz yapılaşma" olarak nitelendirilen dokuların düzene uyumlanmasına dayandığı anlaşılmaktadır. 2007 ve 2008 y1llarında kaydedilen zorla tahliyelerde \% 40'lık oranın kent ölçeğinde gerçekleştiği raporlanırken, bu kentler arasında yer verilen İstanbul'daki tahliyeler, “Avrupa Kültür Başkenti” ünvanının dahil olduğu "mega etkinlikler"7 ile ilişkilendirilmektedir (UN-HABITAT-AGFE $2011,34,35,36)$.

İngiltere'de oluşan bağımsız bir organizasyon olan Bina ve Sosyal Konut Vakfı Geliștirme-Planlama Birimi'nin "İnsanlar Tahliyelerle Nasıl Yüzleşir" başlıklı çalışmasında (BSHF, 2010) -AGFE Raporlarında ele alınanların dışındayüzlerce zorunlu tahliye olayı içinde güncel olan ve karşı direnişin en etkili olduğu düşünülen (BSHF 2010,3) örnekler ele alınmıştır. Buenos Aires (Arjantin), Porto Alegre (Brezilya), Durban (Güney Afrika), Hangzhou (Çin), İstanbul (Türkiye), Karaçi (Pakistan), Santo Domingo (Dominik
Cumhuriyeti) kentleri dışında Mısır'da

MirshÇq and Saranda köylerindeki direnişler incelenmiştir.
Zorla tahliyelerde, yeniden yerleştirme sağlansa bile, süregelen yaşam alışkanlıklarına aykırı mekanlar, travma ve yaşam alışkanlıklarında değişime bağ $l_{1}$ etkiler, önerilen mekanın tahliyeye zorlanan mekan ile arasındaki değer farkı, yapı niteliğinin farklılığı, sağlanan mekanların kent merkezine uzaklığ ulaşım ve servislerin kısıtlılığ 1 ile iş ve sosyal yaşam kalitesindeki ani düşüşler gibi birçok kaybın telafi edilmediğ $i$ anlaş1lır. Bu örneklerde (BSHF 2010, 4), mülkiyet hakkı dışında, barınma hakkı, sosyal haklar ve yaşam hakkını ihlale yönelen ve "devlet eliyle" desteklenen şiddete karşı direnişte "kamu otoriteleri ile müzakere, yaşamak için işgal, davalar ve diğer yasal kanallar, açık mücadele, direniş ve politik perspektifler, hak ve politikaları inşa etmek, kampanya seferberliği”" gibi yöntemler öne çıkmaktadır. Ayrıca direniş̧in her biçimi ve aşamasında yaş, etniklik ve cinsiyet faktörlerinin de etkili olduğu belirtilmektedir. Süregelen direniş örneklerinde, farklı etnik, cinsiyet ve yaş gruplarından insanların bir araya gelmesine rağmen, kadınların ön saflarda aktif olması, gerek orantısız güç kullanımına yönelik kamuoyu tepkisini arttırması, gerek güç kullananların verdiği hasar ve şiddeti azaltmakta avantaj sağlamaktadır.

Mekanın baskı unsuru haline geldiği cinsiyet, ırk, din, sınıf ve yaşam tarzına bağlı ayrımcılık içeren ve çoğunlukla çok kültürlü kentlerdeki tahliyelerde marjinal olarak nitelendirilen bölgelerde, soylulaştırma ${ }^{8}$ olarak kavramsallaşmış üst kültür gruplarının yerleştirilmesi amaçlı tahliyeler hakim olmaktadır. Bu örneklerde, mekanların kentsel ve bölgesel ölçekte yeniden planlanmasının arka planında, kültür ve ekonomi politikaların 
birlikteliği bulunur. Her ne kadar günümüzün neoliberal kavramı ile ifade edilen düzeneğinde ekonomik faydaya odaklılık vurgulansa da tarihsel, teolojik, ve ırksal bir dizi öğreti arasındaki çekişmelerde, kitleleri ve aidiyetlerini yeniden biçimlemekte mekanın kullanıldığı örnekler artmaktadır. Bu artışta neoliberalizmin, eleştirel teorilerde de baskın olarak kullanılan "ranta dayalı" söylemini tekrarlaması, mekan üzerindeki baskıcı, eşitliksiz, şiddet içeren diğer ilişkileri önemsizleștirmekte ve hatta gizleyebilmektedir. Bu söylem gibi soylulaştırma söylemi de müdahale edilen bölgede yalnızca bir sınıfsal geçiş ve mekânsal yenileme olacağ izlenimi ile arkasındaki ırk, cinsiyet, din ve yaşam tarzı farklılarına bağlı ayrımları kamufle edebilmektedir.

1990'lardan itibaren, mekan üzerine yapılan cinsiyet çalışmalarında, tasarımcıların toplum içinde normal olarak genelleşen ahlak yaklaşımının yalnızca farklı etniklikler arasında bir ayrıșma oluşturmayıp aynı zamanda tasarımda cinsiyetçi ayrımcıllı̆̆ı özellikle mimaride kendini gösterdiğini ortaya koymaktadır. Feminist perspektif, 20. yüzyılda mekanda kadın-erkek arası dikotomik/ikili ayrımın üç farklı ölçekte insan bedeninden, mimari yapıya ve insan yerleşimlerindeki mekânsal dokulara yansımalarını ele alır. Mimari biçim ve biçemdeki eril ya da dişil biçimlerin, metafor olarak kullanımı dışında, mekanın tasarımında cinsiyet rollerini belli kalıplar çerçevesinde biçimleyen ve baskılayan, oran, ölçü, işlev, düzen gibi nicel değerlerin kalıplaşmış cinsiyet rollerine göre ayrıştırılması eleştirilir. Weisman (1992), benzer bir bakış açısıyla, 20. yüzyılda mekan-cinsiyet ilişkilerini, modern ve post-modern mimari tutumlar içinde de ele alınır. Elizabeth Wilson, 20. yüzyıl başında mekana yansıyan cinsiyetçi unsurların, modern mimarinin getirdiği biçim ve biçemde cinsiyetsizleşme ile kısmen giderildiğini belirtir. Ancak Wilson (1991, 100-135), aynı bağlamda, farklılık, çeşitlilik ve özgürleşme mekanı olarak metropolleri yücelten modernitede halen bir takım erkek egemen ${ }^{9}$ unsurların -özellikle Orta Avrupa'dasürdürüldüğünü ve modern kentsel önerilerin kentteki düzensizliklerin hepsini yıkarak düzene sokan, aşırı hiyerarşik yaklaşımını da değerlendirir.

Wilson'a $(1991,115)$ göre, modernist mimarların düşlemiş olduğu sınıfsız ütopya, yeni bir politik düzene koșullanmıştır. II. Dünya savașı sonrası bu yaklaşımların yokluğunda ise, kalabalıklaşmış, kirli, yabancılaşmış yapılı çevrelerin' ${ }^{\circ}$, "pişmanlık yaratan emlak yı ̆̆ınları" ve "iç karartıcı iş merkezlerinden" -1960'lardaki kırılma dışında- hakim olmaya başlamıştır. Wilson, endüstrinin üçüncü dünya ülkelerine kayması ile bu kategorileştirme içinde yer alan kentlerde kendini gösteren nüfus yoğunlaşmasina bağlı gecekondu mahallelerinin Batı kökenli teorilerin belirlediği normallik anlayışına bağlı olarak ele alınmasını eleștirir. Wilson (1991, 123), bu bakış açısında duran Batılı araştırmacı ve planlamacıların bu kentlere, "kendi kentlerinde yaşayanların önceden sahip oldukları ahlaki, fiziksel, kalıtımsal refahı uzatmak adına, üçüncü dünya kentlerini batının akraba kentleri olarak nitelendirip", kendi kentlerindeki en kötü problemlerin abartılmış karikatürleri muamelesi yapmalarına değinir. Oysa (Wilson 1991, 130), bu varsayımların normallik kabulleri ve çekirdek ailenin evrenselliğini olumlayan, genelleyici tutumunun aksine, Üçüncü Dünya kentleri
9 Patriarchal (Ing.)

10 Wilson'a (1991, 115$)$ göre, bu olgu postmodern yaklaşımin devreye girmesi ile iyice karmaşıklaşan kentlerde belirgin olmaktadir. 
olarak ele alınan kentlerin nüfuslarında, Latin Amerika'nın gecekondu nüfusunda gözlemlenebileceği gibi -özellikle kadınlarda- bu normallik anlayışını aşan özgürlüklerin hakim olduğu çıkarımı yapilır.

Cinsiyet ve mekan çalışmalarının gündeminde ortaya çıkan bir başka norm y1kıcı tutum ise hetero-normatif cinsiyet örüntülerinin taşıyıcısı olan kodları red etmektir. Belirleyici cinsiyet kimliklerini tümüyle reddeden queer teorisi, mevcut cinsiyet kalıplarını yıktığı kadar, verim ve organizasyona koşullu yapılı çevreye ilişkin cinsiyetlendirilmiş kalıpları da çözündürmeye yönelir. Queer kavramı, tuhaf, eşcinsel gibi kelime anlamlarının ötesinde belirli bir tanım ortaya koymamakla birlikte, cinsiyete bağlı kalıplaşmış kimlikler ve bu kimliklerin göstergelerine bağlılık göstermemek anlamında kullanılır. Ayrıca, süregelen ve toplum tarafından cinsel kimliğin göstergesi olabilecek davranışlar da dahil olmak üzere tüm biçimlerin bozarak kullanımını ifade eder. Queer (Butler 2010), kadın-erkek ikiliğini/dikotomisini norm olarak dayatan, toplum tarafindan yapılandırılmış ve kamusal iktidarın sürekliliğini koruduğu geleneksel heteroseksüel kalıpların yıkımı olarak anarşist bir tutum oluşturmaktadır. Benhabib (1999, 288-289), Butler'1n cinsiyet ve toplumsal cinsiyet çakıştırması üzerinden gelişen eleştirel teorisini onaylamakla birlikte, bedenin cinsel yapılanmasının kültürel olarak inşa edildiği yolundaki yaklaşıma karşı çıkar. Bourdieu (2001, 21), "eril dominasyon" gibi cinsiyetçi şiddetin kültüre sızmış bir takım örüntüler ile yaygınlık kazandığı görüşünü Antik Yunan ve Roma kültüründe homoseksüelliğin olumsuz nitelendirmelerle aşağılanması üzerinden örneklerle destekler. Betsky'nin çalışmasında (1997), queer kavramı, mekan ve kentler ile kurulan ilişkide, queer mekan, belli nitelikler ile görülür olmaktan çok mekanda süregelen ve cinsiyeti çağrıştıran biçim, düzen ve kalıpların abartılı ve karışık kullanımlar yoluyla yıkımı ile öne çıkar. Bilinen mimari biçimler ve biçemlere göre tasarlanmış ve düzenlenmiş mekan, queer mekanda tekinsiz, birbiri ile uyum ve bağdaşıklık gösterme kaygısından uzak ve özgürce tersine çevrilir. Betsky'nin ele aldığı bağlamda bu tutum, mekan üzerinden kurumlaşmış sosyal pratiklerden özgürleşmenin ifadesidir.

Queer teori eleştirileri, son y1llarda kentsel dönüşümde "çöküntü alanların ıslahı" gibi başlıkların, toplumun geneli tarafından kabul edilen cinsiyet ve ahlak kalıplarının dışında yaşayanlara karşı ayrımcılık ve baskıyı meşrulaştırma aracı olarak kullanımlarına dikkat çekmektedir. Kentlerde bu biçimde ötekileştirilenler, psikolojik ve fiziksel şiddete uğradığ kadar mekânsal olarak kendilerini tecrit etmek zorunda kalmakta ya da edilmektedirler. Irk, din, kültür, cinsel eğilim, meslek, yaşam tarzı, sosyoekonomik konum gibi nedenler ile ötekileştirilenlerin bir arada yaşadığ 1 alanlar, kent sosyolojisi kadar gündelik yaşamda kullanımı dünyada genelleşen ve Avrupa kökenli getto gibi genelleyici bir mekânsal kavramla ele alınır. Erder'e $(2006,3)$ göre bir yerin getto olarak adlandırılması için orada "ayrımcılı̆̆ın şiddetli boyutta olması gerekir". Oysa, bu ayrımcılık biçimleri, tüm kent mekanlarında ortaya çıkabilmektedir. Bu bağlamda, Türkiye'de getto olup olmadı̆̆ sorusunu daha detaylı bir çalışmaya ileten Erder (2006, 9), gettonun "Tarlabaş1 gibi alanlar için kullanılan”, “çöküntü alanı” 
kavramından farklı olduğunu, bu gibi alanlarda gettolarda belirgin olan tecridin olmadı ̆̆ını belirtir. Yine de Tarlabaşı gibi bölgeler üzerine kurgulanan kent mitleri, ayrımcı bir söylemi yaygınlaştırarak, ötekileştirme/marjinalize etme yoluyla zorla tahliyeleri haklı çıkartma niyeti barındırmaktadır.

İnsan ve mekan üzerine baskıyı temsil eden kavramlar ve mekânsal örnekler, insanlar arası güç ilişkileri ile başlayıp, günümüze kadar gücün temsil bulacağı değerler ve yapıların oluşmasına paralel olarak artmaktadır. Bu bağlamda, baskının ve ayrımcılığın, 20. yüzyıl boyunca özellikle, iki dünya savaşı sonrası yeniden yapılanma sürecinde, güç temsillerinin, sistemlerin ve diğer yapıların yoğunlaştığ kentlerde ağırlık gösterdiği ve bunu günümüzde de sürdürdüğü gözlenebilir. Böylece girilmiş olan yeni süreçte, küreselleşme eğilimine giren kentlerin güç göstergelerinde artış sağlamak yoluyla simgeleşmesi, insan-çevre-mekan ilişkileri üzerine kurulan araştırma ve söylemleri de ağırlıklı olarak göstergelerin toplu halde incelenebileceği bu kentlere odaklamıştır. Kentler üzerine yapılan sosyolojik çalışmalar ve üretilen yeni kavramlar da, insan hakları yanı sıra, barınma hakkı, çevre hakkı gibi tanımlar üzerinden gelişmiştir.

Lefebvre'in 1968'de ilk kez kullandığ 1 (2003), Harvey'in (2008) New Left Review dergisinde yayınlanan ve sonrasında Asi Şehirler (Rebel Cities)'de yorumladığ 1 makalesi ile yeniden ele aldığ 1 "kent hakk1"'I kavramı, insan, mekan ve özgürlük ilişkilerinin, politik kurgular ve sistemler ağı olan kentler üzerinden incelenmesi eğilimini arttırmıştır. Lefebvre (2007) öncelikle, günümüzde bürokratik olarak yapılanmış tüketici toplumunu anlamanın iyi bir yolu olarak kentlerde oluşmuş gündelik hayatın referans alınmasını önerir. Böylelikle yaşamı kısıtlayan baskılayan unsurlar tespit edilip çözündürülebilme ihtimaline kavuşur. "Kent hakkı" kavramının kullanımlarında, söylem her ne kadar kentten dışlananların hakları üzerinden kurulsa da, insan-çevre-mekan ilişkileri bağlamında değerlendirmeler, toplumsal bir yaşam, çağdaş kent ve barındırdı $\breve{~} 1$ sistemler ağı, sınıfsal çatışmalar, demokratik kenti formüle etmek gibi yapılar çerçevesinde kent sorununa odaklanır. Ancak, Harvey'in (2008) "Kent Hakkı" başlıklı çalışmada belirttiği gibi, artan eşitsizliğin, özellikle 21. yüzyıl boyunca denetimin küresel bir güçler ağı ile kentlerde yoğunlaşması, -Lefebvre'in devrim olarak nitelendirdiği- bu eşitsizliği yıkacak karşı hareketin kentlerden çıkmasını gerekliliğini karşılar. "Kent hakkı", günümüzde, dünyanın farklı kentlerinde ortaya çıkan kent hareketlerine ve bildirilerine referans olan önemli bir kavram olarak tartışmalarda yer bulmaktadır. Lefebvre'in "Kentsel Devrim" ve Harvey'in "Asi Şehirler" (2012) olarak kitaplaşan çalışmaları, kentlerde başlayacak yaratıcı ve yıkıcı hareketlerin potansiyeline inanan olumlu yaklaşımlardır. Bu çalışmaların ele aldığg gibi, 21. yüzyıl boyunca ortaya çıkan ve mevcut baskı mekanizmalarını aşmak ya da sarsmakta öne çıkan tutum ve hareketlerin, günümüzde küresel bask1 ağlarının yoğunlaştığ 1 , merkezi konuma gelen kentlerdeki örnekleri bu olumlu yaklaşımları haklı çıkartacak düzeye ulaşmaktadır. Kentsel mekanda kendini gösteren baskı odaklarını hedefleyen büyük çaplı sokak eylemleri, Lefebvre ve Harvey'in kent devrimini anlamda realize etmiştir.

Harvey'in “Kent Hakkı"nda (2008)

II Right to the city (Ing.) 
planlarına radikal bir biçimde yansıdı ̆̆ Haussmann Paris'i Paris Komünü, Moses New York'u ise 1968 ayaklanmalarında tahrip edilir. Bu hareketlerin, kentin mekan hiyerarşisinin kapitalizme uyumlandı $\breve{g} 1$ kentlerde yoksullar ile varsıllar arasında olduğu kadar merkezçeper arasında oluşan gerilimler ile başlar. Kent devriminin yeni biçimi, Childe ve diğer klasik kent tarihçilerinin sınıfsallaşma ile başlayan kırsal-kentsel ayrımında kullandıkları kent devrimi tanımlarını gündelik kent yaşamı bağlamında yorumlanmaktadır. Lefebvre ve Harvey yorumlarında kent devrimi, kenti, siyasi, ekonomik ve sınıfsal iktidar yapıları gibi baskı araçlarının pasifleştiği bir uzam olarak kavramakta kullanılır. Harvey (2012, 115-120) “Asi Şehirler”de, Paris Komünü devamında dünyanın birçok yerinde ortaya çıkan isyan ve eylemlerin kent sokaklarında doğup farklı ülkelerde eş zamanlı etkiler oluşturduğunu ve bu ayaklanma ve hareketlerin süreklilik gösterdiği kentlerde odakta olan kent mekanları ile birlikte anıldığını vurgulamaktadır. Harvey'e (2012, 115-120) göre Paris Komünü ile tarihsel görünürlüğ̈unü arttıran ve hafızalara kazınan eylemler birçok Avrupa kentinde, Rus Bolşevik Devrimi ayaklanmaları Doğu Bloku ve Orta Avrupa ülkeleri, 60'larda başlayan eylemler dünyanın bir çok farklı noktasında etki bırakmıştır. 2003'te Amerika'nın Irak'a açtığı savaş karşıtı eylemler, 2008'de küresel kriz ile, 2010'da Arap Dünyası ve Ortadoğu'da başlayan eylem ve işgaller farklı nüfusları barındıran büyük kentlerde yansımalar bulmuş, güncel olarak Tahrir Meydanı (Kahire), Rabin Meydanı (Tel Aviv), Plaza del Sol (Madrid), Wall Street Zuccotti Park (New York), Sentagma Meydanı (Atina),

12 squatting (Ing.)

13 Dissent (lng.)
Tiananmen Anıtı (Pekin) gibi yüzlerce kentsel mekan direniş mekanı olarak siyasi sınırlardan bağımsız olarak kollektif hafızaya yerleşmiştir. İstanbul'da Taksim Meydanı da bu bağlamda simgeleşmiş bir mekandır. Berlin'de Potsdamer Platz, Londra'da Trafalgar Meydan'1 kentin merkezi konumu ve bu noktada toplumsal hafızada edindiği yer ile simgeleşmiş mekanların dönüşümünün de uzun süreli protestolarla tepki bulduğu bilinmektedir.

Günümüze kadar, küresel ölçekte bask1 araçlarını yıkmayı hedef alan toplu hareketlerin, farklı birey ve toplulukları kapsayacak şekilde, ekonomik, sosyal, kültürel ve mekânsal eşitsizliğin yoğunlaştığı, insanların yaşam alışkanlıklarında keskin dönüşümlere maruz bırakıldığı tüm uzamlarda benzer biçimde ortaya çıktığı ve yayıldı ̆̆ 1 görülür. Kimi zaman mekan, yaşam üzerinde baskı oluşturan unsurlara karşı direniş ve eylemde simgeleşmek yanında, bir ifade aracı olarak da kullanılmaktadır. Toplu eylemler dışında, barınma sorununun çözümsüz kaldığı Güney Amerika, Güney Afrika ve Hindistan'da yüzyıl boyunca yoğunluk gösteren arazi ya da bina işgalleri, politik, sosyal, sanatsal ya da anarşist yaklaşımlarla başkasının boş mülküne izinsiz yerleşme anlamına gelen izinsiz yerleşme ${ }^{12}$ biçiminde görülmüştür. 1980'lerden itibaren ise, dünyanın birçok kentinde özel mülkiyete karşı bir eylem olarak yaygınlaşmıştır. İzinsiz yerleşmeler, barınma ihtiyacı dışında, mekan kullanımını yasal sınırlarla belirleyen mülkiyete karşı bir eylem biçimi olarak da görülmektedir.

İşgal ederek mekanlaşma insanoğlunun en erken mekanlaşma deneyimlerinden biri olmasına karşın, hakim kalıplar ve normların reddi biçiminde muhalif'13 ve anarşist işgal biçimi olan izinsiz 
yerleşmenin daha eski örnekleri de vardır. Bilinen erken örnekler arasında, 17. yüzyılda İngiliz İç Savaşı'nda da aktif olan Kazıcılar'4 grubu mülkiyet ve devlete karşı tutumlarıyla da öne çıkmaktadır (URL 8, 2012). William Everard ve Gerrard Winstanley'in öncüsü olduğu WybridgeSurrey'de St. Georges Tepesi adı verilen alanın işgali ile başlayan hareket, 1648 yılından 1650 yılında dağıtılana dek, kendilerini eşitlik ve özgürlük yanlısı olarak tanımlayan bir çok gruba örnek olmuştur. İngiltere'nin çeşitli bölgelerinde, Kazıcılar'ın eşitlikçi kolektif ve tarıma dayalı yaşam biçimleri bu gruplar tarafından da sürdürülmüştür. 1911 yılında St. Georges tepesi, W.H. Tarrant tarafından golf sahasına, 1920 yılında içinde 420 lüks konut da barındıran ülkenin ilk golf kulübüne dönüştürülerek, günümüzde dünya emlak piyasasının en pahalı bölgelerinden biri haline gelmiştir's. Amerika San Francisco'da Diggers adını kullanan ve açıkça İngiltere'deki Digger'lardan esin aldıklarını belirten bağımsız işgalci bir grup "özgür kenti yaratmak için sokaktayız" sloganı ile 1960'ların sonundan günümüze sokak etkinlikleri, tiyatrolar ve anarşist eylemler organize etmektedir. Bu eylemlerde, 17. yüzyıl İngiliz Digger'ların kırsal kesimde kollektif tarım ve üretime dayalı komün yaşam biçimleri 21. yüzyıl Amerikan Kazıcılar'1 tarafından yeniden üretilmektedir (URL 9, 2013).

İzinsiz yerleşme 1980'lerden itibaren gelişmiş ülkeler kategorisinde anılan ülkelerde de yaygınlaşmaya başlayan bir harekete dönüşmüştür. Alternatif mekân, barınma, konut sorunu, eşitsizlik, kentlerde yaşam ve ifade alanlarının daralması nedeniyle sosyal ve kültürel yeni ortamlara olan gereksinim, politik bir eylem, işgal edilen mekanın korunması ya

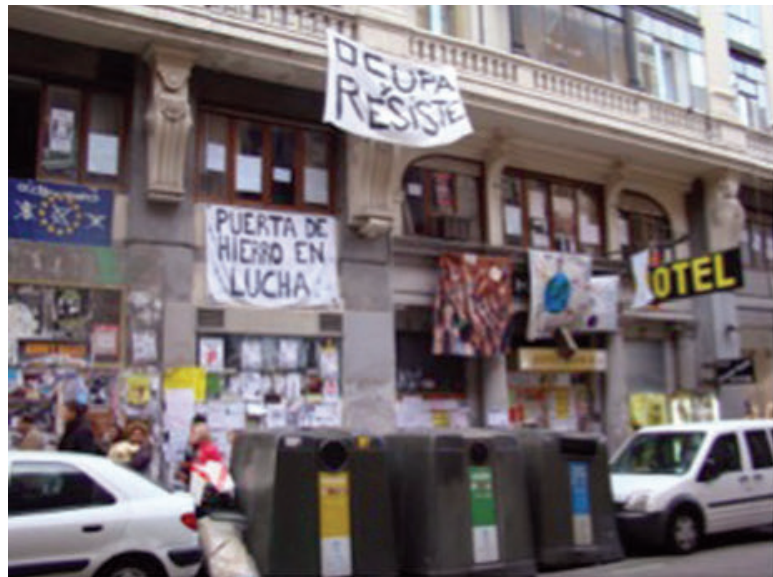

Resim: 7

ispanya'da Mayis is protestolarında isgal edilen Hotel Madrid (Eser Yağfı, 20II). da yaşam tarzına uyumlanan mekan olarak işgal evi' ${ }^{16}$, mekanın geleneksel ve yasal tüm kalıplar ve normların dışında kullanılması ve mülkiyetin reddi ile karakterize olur. İşgal edilen mekan, toplumun genelinden, düşünce ve eylemde ayrışan ya da dışlanmış olan bireylerin bir araya geldiği kolektif-bireysel bir uzam belirlemesi nedeniyle kentin uyumlayıcı ve baskıcı unsurlarını kısmen çözündürmeye yönelir. Bu unsurlara karş1 çıkışın başka ifade biçimleri arasında duvar yazıları ve grafitilerin bazı türleri de bulunabilir. Bu ifade biçimlerinin mekan üzerinde kontrol ve iktidara karşı gerçekleştirdikleri saldırı Baudrillard'a $(2002,131)$ göre katılım ve yenilenmeye olan ihtiyacın dişavurumudur. Grafitiler mekanı özgür ifade aracı olarak kullanıp kentin tüm yüzeylerini kural tanımaksızın kuşatırken, toplumsal olaylar ile simgesel hale gelen kent meydanlarına yakın ve kent belleğinde yer edinmiş kimi yapılar karșı hareketlerin ifade mekanları haline gelmektedir (Resim 7 ve Resim 8).

Mumford'a (2007) göre, kentleşme ile dışlanmış ya da yabancılaşmış gruplar arasındaki grupların oluşumu ve bunların hakim mekânsal ve sosyal kalıpları reddeden tutumları ile oluşan karşı hareketlerle belirginleşmiştir.

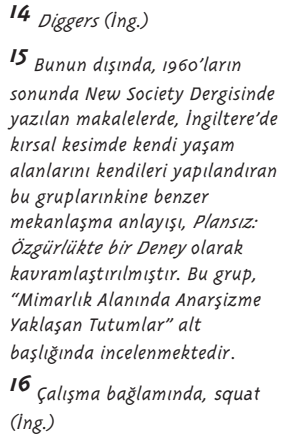
kırsal kesimde kendi yaşam alanlarını kendileri yapilandıran bu gruplarinkine benzer mekanlaşma anlayışı, Plansız: özgürlükte bir Deney olarak kauramlaştırılmıştır. Bu grup, "Mimarlık Alanında Anarşizme Yaklaşan Tutumlar" alt bașlı̌̆lnda incelenmektedir. 16 çalışma bağlamında, squat (Ing.) 


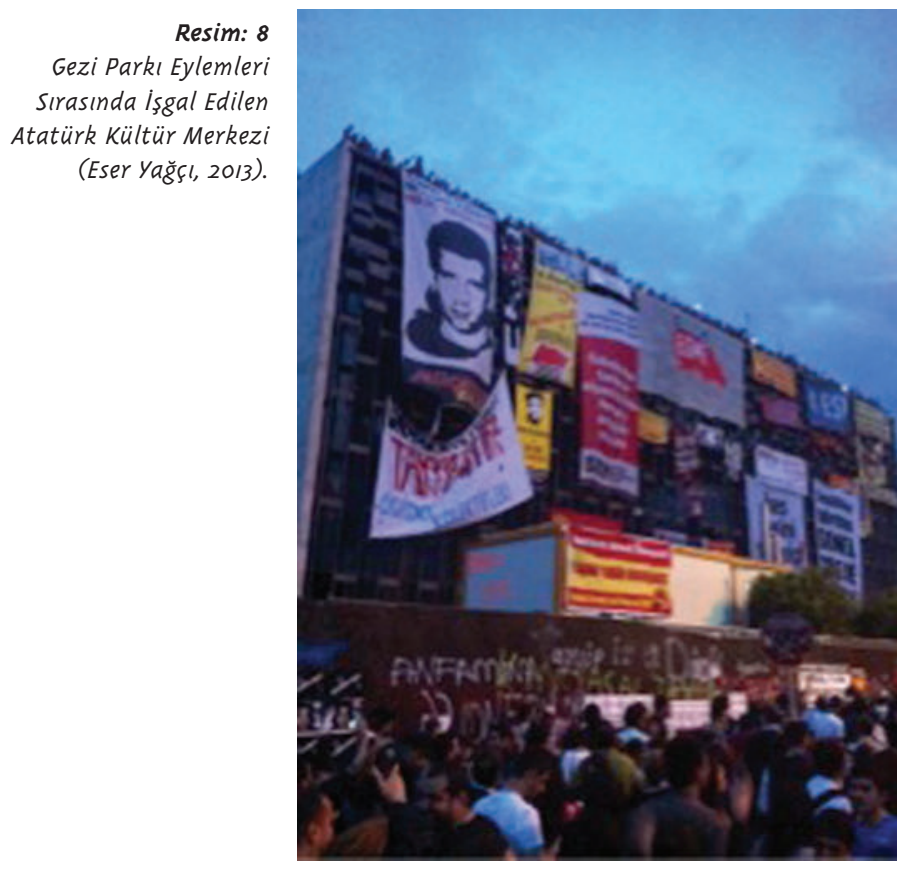

6. yüzyıldan itibaren poliste (Mumford 2007, 250-253), sonrasında Çin, Hindistan, Pers, Yakın Doğu ve Batı'da gizemci öğretiler ile sürmüştür. Gücün mülkiyette temsil bulmasıyla, yaşam biçimini kısıtlayan yapıların gücün sürekliliği ile bağı doğrultusunda, bu grupların karşı durduğu hedefe mülkiyeti koymaktadır. 6. yüzyılda beliren karşı tutumlardan çok önce, "egemen bir azınlı̆̆a" fayda sağlayan mülkiyetin kötülüğ̈̈ “'Asurlular'a ait bir tablet” ve Gılgamış Destanı'nda “Utnapiştim'de ifade bulur". Mumford'a (2007, 143) göre, kentleşme ile sınıf ayrılıklarının yapılanmasının temelinde yatan mülkiyet ilişkileri ile ilgili ayrıntılı yasalar, M.Ö. 1700 gibi erken bir dönemde Hamurabi Yasaları'ndan bu yana kentlerde ayrıcalıklı olanlar ve olmayanları, sosyal ve mekânsal olarak ayırmaktadır. Proudhon $(2010,97)$ için ise mülkiyet, iktidarı temsil eden erkin dayattığ 1 kuralların statüko haline gelmesine neden oluşturur. Proudhon'un (2010) tanımlarında, mülkiyet ile dünyada yaşayan tüm canlıların kullanımında olan hava, su ve toprak güç unsurları sahiplenilip başka güç temsilleri ile takas edecekleri biçimde hiyerarşik olarak bölüşülür ya da bölüştürülür.

Günümüzdeki siyasi sınırların oluşumu ve bu sınırlar için günümüze dek yapılan tüm savaşlar, ölümler ve yıkımlar arkasında mülkiyet ilişkileri de bulunur. Marx (2004, 692), Kapital'in birinci cildinde, kapitalist üretim tarzının özellikle tarımsal emeği artı güç olmaktan çıkartıp insanların yaşamını sürdürdüğü toprağın mülkiyete geçmesi ile bu topraklardan sürülmeye başlanması ve bu insanlara karşı baskının "mülklerin temizlenmesi” olarak sürdürülmesini ele alır. Ortak topraklar üzerinde yaşam sürdürenlerin bu topraklardan kopartılması ile başlayan yoksullaşma ve devamında, başıboş kalan insanlara karşı baskılar, 15. yüzyıl sonundan itibaren sistematik hale gelmiştir. Marx (2004, 698-706), bu baskıyı, "kanlı" olarak nitelendirdiği Batı Avrupa'da çıkartılan yasalarla ve İngiltere'deki “tarımsal nüfus" üzerinden örneklemiştir. İngiliz İç Savaşı’na neden olan gerilimlerin ve ayaklanmaların başında, ortak topraklar üzerinde oluşan özel mülkiyet ile bu toprakları daha önce kullananların topraktan kopartılması da yer alır.

Marx'ın Kapital'de (2004) kurduğu ilişki, mimarlık disiplininin gelişimi üzerinden, insan ve mekan arasında kurulacak olduğunda, insanın yaşamını sürdürdüğü, deneyimleri, alıșkanlıkları ve anılarını biçimleyecek mekan üretiminden kopartılması söz konusudur. Marx'ın, insan doğası, baskı unsurları ve yabancılaşmaya ilişkin teorileri bu bağlamda mekan yapma edimini örgütleyen mimarlık için de geçerli bulunabilir. İnsanın, çevresini üretme 
edimi, onu diğer hayvanlardan ayırdığ gibi kendi varlığını gerçeklemeyi sağlar. Arendt (2012), insanın yaşamda edindiği amaçl1- bu üretim tarzının, insanı dünyayı nesnel olarak biçimleyebilen diğer hayvanlardan ayıran ve kendi varlığını zihinsel etkinliğinin ispatı ile anlamlı kılan bir özellik olarak ele alır. Bu temelde, Arendt'in (2012, 357-368) Marx'in kuramından yola çıkan yabancılaşma yorumu, üretim öncesinde öznel tasarının belli bir kitlenin ya da bu geçici kitlenin üretim koşul ve kurallarını tespit etmesi, insan üretiminin işe dönüşmesi üzerine kurulur. Bu yorumda, amacin sermeye birikimine ve belli bir kastın özel mülk bölüşümüne odaklanması, insanı mülkiyet ilişkileri üzerinden ekonomi-politikalara tabi kılarak, kendi öznel dünyasını anlamlı kılacağı bir üretimden, kimliğin yeniden üretildiği bir nesnel üretime ya da tüketime koşullanması olarak anlaşılabilir.

Mekana hakimiyet, insanın yaşamı anlamlandırırken belirlediği erk/güç temsillerinin belirlenmesiyle başlamış, erki temsil edenlerin, insanı biçimlemekteki etkisi doğrultusunda yeni mekânsal kurgulara gereksinmesi ile gelişmiştir. İlk yerleşimlerin kentlere dönüşmesi de topluluk içinde daha güçlü olanlar ile güçsüz konumda olanların ayrışarak oluşturduğu toplumsal katmanlaşmanın mekânsal farklılıklar biçiminde karşılık bulmasıdır. Daha sonradan oluşan yasalar ve mülkiyet tanımları yanı sıra, bu tanımları belirleyen iktidar yapıları tarafından üretilen normlar ile mekanı oluşturacak standartlar da belirlenmek durumunda olmuştur. İnsançevre-mekan ilişkilerinin politikalara tabi olmasında, temelde bu gelişmeler -özellikle mekan yapma ediminin normlaşmasında- etkili olmuştur. Mekanı kurgulamakta bu normları üretenler ve kullananlar, normlar kadar bilgi ve düşünce alanını geliştiren mimarlığın yetki sınırlarını belirlemiştir. Daha önceden kendi mekanını tanımlayan ve üreten insan, mekan yapma edimini gerçekleştirecek olanların/mimarın yetkileri belirlendiği kadar kullanıcı olarak konumlanıp mekan üretiminden kopartılmıştır. Böylece mimar, mekan üretiminde iktidar sahibi olduğu yanılsaması ile bu normların sınırlarında, mekanı ve mekanda yaşamı kurgulama rolünü üstlenmiştir. Bu kurgu, başta bu normlar tarafından sınırlanmış olduğundan, sonrasında mülkiyet sınırları içinde kalmak zorunluluğundan, insançevre-mekan ve ilişkisinde özgürlük içermez. Bu nedenle anarşist bir mimarlıktan bahsedilemez. Ancak mimarlık alanında sınırları zorlayan tutumlar olabilir. Bu tutum ile öne çıkan mekânsal kurgu, tartışma ve öneriler özgürlüğün mekânsal temsilleridir

Kaynakça

Arendt, H. 2012. İnsanlık Durumu. Çev. Şener B.S., İstan bul: İletişim Yayınları.

Başaran, B. 2007. Osmanlı'da Asayiş, Suç ve Ceza: 18.-20. Yüzyıllar. Der. Lévy, N. ve Toumarkine, A., İstanbul: Tarih Vakfı Yurt Yayınları.

Baudrillard, J. 2002, Simgesel Değiş Tokuş ve Ölüm. Çev. Adanır, O., İstanbul: Boğaziçi Üniversitesi Yayınevi.

Benhabib, Ş., 1999. Modernizm, Evrensellik ve Birey: Çağdaş Ahlak Felsefesine Katkılar. Çev. Küçük, M., İstanbul: Ayrıntı Yayınları.

Betsky, A., 1997. Queer Space: Architecture and Same-Sex Desire. New York: William Morrow and Company, Inc..

Bourdieu, P., 2001. Masculine Domination. Tr. Nice, R. Stanford University Press, Stanford, California.

BSHF 2010, How People Face With Evictions, Erişim Yeri: http://www.bshf.org/news-events/newsdetail.cfm?lang $=00 \&$ thenewsitemid $=\mathrm{d} 9276 \mathrm{~b} 61$ 15c5-f4c0-994994a3688f4044, Erișim Tarihi: 27 Kasım 2010

Butler, J., 2010. Cinsiyet Belası: Feminizm ve Kimliğin Altüst Edilmesi. çev. Ertür, B., İstanbul: Metis Yayınları.

COHRE, 2013. Annual Report, Erişim Yeri: http://www.cohre.org/sites/default/files/annual_report_2009. pdf, Erişim Tarihi: 15 Kasım 2013.

Davis, M., 2007. Gecekondu Gezegeni. Çev. Koca, G,. İstan 
bul: Metis Yayınları.

Dirlik, A., 2010. Post Kolonyal Aura: Küresel Kapitalizm Çağında Üçüncü Dünya Eleştirisi. Çev. Doğduaslan, G., İstanbul: Boğaziçi Üniversites Yayınevi.

Erder, S., 2006. Refah Toplumunda Getto. İstanbul: İstanbul Bilgi Üniversitesi Yayınları.

Foucault, M., 2000. Hapishanenin Doğuşu. Çev. Kılıçbay, M.A., Ankara: İmge Kitabevi.

Galtung, J., 2001. Gandhi ve Alternatif Hareket Teoride Satyagraha - Normlar, Kamu Vicdanına Çağrı: Sivil İtaatsizlik. çev. Coşar, Y., İstanbul: Ayrıntı Yayınları.

Harvey, D. 2008. Right to the City, New Left Review-53, Sept.-Oct. 2008 http://newleftreview.org/II/53/david-harvey-theright-to-the-city

Harvey, D., 2012. Rebel Cities: From Right to the City to the Urban Revolution. Verso Books, London, New York.

Karamustafa, A.T., 2007. Tanrının Kuraltanımaz Kullarıİslam Dünyasında Derviş Toplulukları 12001550. İstanbul: Yapı Kredi Kültür Sanat Yayıncilık.

Karatani, K., 2008. Transkritik: Kant ve Marx Üzerine. Çev. Ünal, E., İstanbul: Metis Yayınları.

Leach, N., 1999. Architecture and Revolution: Contemporary Perspectives on Central and Eastern Europe. London: Routledge.

Lefebvre, H., 2003. The Urban Revolution, Trans. Bononno. Minneapolis: R., The University of Minnesota Press.

Marx, K., 2004. Kapital. Çev. Bilgi, A., Ankara: Sol Yayınlar1.

Massey, D., 1999. Imagining Globalization: PowerGeometries of Time-Space, in Global Futures: Migration, Environment and Globalization, Eds. Brah, A., Hickman, M.J. and Ghail, M.M., London: MacMillan Press Ltd.

Miles, M., 2008. Urban Utopias: The Built and Social Architectures of Alternative Settlements. New York.: Routledge,

Mumford, L., 2007. Tarih Boyunca Kent: Kökenleri, Geçirdiği Dönüşümler ve Geleceği. Çev. Koca, G. ve Tosun, T., İstanbul:Ayrıntı Yayınları.

Müller-Wiener, W., 2007. Ístanbul'un Tarihsel Topografyası: 17. Yüzyıl Başlarına Kadar ByzantionKonstantinopolis-İstanbul. Çev. Sayın Ü., İstanbul: Yapı Kredi Yayınları.

Proudhon, P.J., 2010. Mülkiyet Nedir? Veya Hukukun ve
Yönetimin İlkesi Üzerine Araştırmalar. Çev. Çetinkasap, D. , İstanbul: Türkiye İş Bankası Kültür Yayınları.

Weisman, L.K., 1992. Discrimination by Design: A Feminist Critique of the Man-Made Environment. Chicago: University of Illinois Press.

Wilson, E., 1991. The Sphinx in the City: Urban Life, Control of Disorder, and Women. London: Virago Press, .

Stolleis, M., 2009. Yasanın Gözü: Bir Metaforun Tarihi, Çev. Çağlar, A., İstanbul: Kitap Yayınevi.

UN-HABITAT AGFE, 2011. Forced Evictions: Global Crisis, Global Solutions, Erișim Yeri:

http://www.unhabitat.org/pmss/getElectronicVersion.aspx?nr =3187\&alt=1 25 Erișim Tarihi: 14 Aralık 2012

URL 1

http://www.cathar.info/1204_origins.htm The Cathars, Erişim Tarihi:04 Haziran 2012

URL 2

http://www.midi-france.info/08_buy.htm Erişim Tarihi: 04 Haziran 2012.

URL 3

http://www.auroville.org/journals\&media/avtoday/oct_2002/h ousing_anarchy.htm , Erişim Tarihi:11 Mart 2012.

URL 4

http://www.auroville.org/journals\&media/avtoday/october_2003/auroville_unity.htm Erişim Tarihi: 11 Mart 2012.

URL 5

http://www.auroville.org/environment/villages/sewa.htm SEWA. Erişim Tarihi:11 Mart 2012.

URL 6

http://www.auroville.org/thecity/centre_for_urban_research.ht m Centre for Urban Research. Erişim Tarihi:11 Mart 2012

URL 7

Ashram History, Erişim Yeri:

http://www.gandhiashram.org.in/index.php?option=com_content\&task=view\&id=20\&Itemid=41. Erişim Tarihi: 27 Şubat 2012.

URL 8

http://exlibris.org/nonconform/engdis/diggers.html Diggers. Erișim Tarihi:15 Kasım 2012.

URL 9

Who were (are) the Diggers?, Erişim Yeri: http://www.diggers.org/overview.htm Erișim Tarihi:15 Subat 2013. 